\title{
複合熱源蓄熱システムの低負荷 MEASUREMENTS ON THE OPERATION 時の運転実測 RESULT IN PARTIAL LOAD OF HYBRID ENERGY HEAT SOURCE SYSTEM AND THERMAL STORAGE TANK
}

\section{高橋淳一 - $* 1$ 近藤雅史 $-* 2$

横尾昇剛— $* 3$ 岡 建雄 - $* 4$ \\ キーワード \\ 複合熱源システム，蓄熱槽，ランニングコスト，エネルギー消費量}

Keywords

Hybrid energy heat source system, Thermal storage tank, Running cost, Energy consumption

\section{Junichi TAKAHASHI $-* 1$ \\ Masafumi KONDOU $-* 2$ Noriyoshi YOKOO $-* 3$}

To meet the stable supply and balanced consumption of energy, we took on a project to extensively introduce hybrid energy and thermal storage tank systems for medium-scale general office buildings. As a result of an experiment conducted on those systems, we succeeded in identifying the way to operate those systems in the most efficient manner. Especially we tested the measurement of changing operation of the heat source equipment in partical load season. This report introduces the actual operation date and effective operation manner of this systems.

1. はじめに

本研究は、電気・ガスの複合熱源と蓄熱槽を有する熱源システム を、中規模事務所ビルに適用した場合の最適運転手法を確立し、省 エネルギー、省ランニングコストを図ることを目的とする。

筆者らは、92 年より本システムを適用した Oビルの実測を続けてお り、熱源の運転順序を変更して、年間の消費エネルギー、ランニング コストがどのように変化するか調査してきた。1 3) ここでは、6 年間の 上記年間デ一タを示すと同時に、発生頻度の高いオフピーク時の低負 荷時をいかに高効率に運転するかを見いだす為、中間期に各種運転 条件を変更して実測した期間中の消費エネルギーやランニングコスト、 機器の成績係数とシミュレーションの結果を報告する。これより、熱源 機器の違いや蓄熱槽の設定温度の違いが、どのようにエネルギー消費 や経済性に影響するかを確認した。

\section{2. 建物及び熱源空調設備概要}

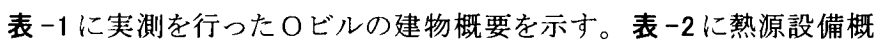
要を、図-1に熱源系統図を示す。以降の表示として、空冷ヒートポ ンプチラーをHP、ガス焚冷温水発生機をABS、蓄熱槽をSTで示す。

\section{3. 運転実態}

\section{1. 年間のエネルギー消費量とランニングコスト}

(1) 年間の運転モード

各年の運転モードを表 -3 に示す。 92 年は夏期も冬期も STをべース 運転とし、次に稼働する機器としてHPを優先運転し、さらに負荷の多 い時にのみABSを運転するHP主体運転を行った。93 年はSTのべー ス運転は同じだが、次に稼働する機器をABSとし、さらなる負荷増の 時に HP を運転する ABS 主体運転としている。この 2 年間のデー夕解 析より、94 年はST をべース運転とし、夏期は ABS を優先運転とし、 冬期はHPを優先運転している。この 3 年間の結果より、 4 年目以降 は 94 年の運転モードで運転を行っている。

\footnotetext{
*1 宇都宮大学工学部建設学科 博士課程

大成建設陎設計本部設備設計部

( $\bar{T} 163-0606$ 新宿区西新宿1-25-1)

*2 宇都宮大学工学部建設学科修士課程

*3 宇都宮大学工学部建設学科 助手・工博

*4 宇都嵬大学工学部建設学科 教授・王博
}

\begin{tabular}{|c|c|c|c|c|c|c|}
\hline \multicolumn{7}{|c|}{ 表 -1 建物概要 } \\
\hline & 所在 & 延床面棈 & 階数 & 権造 & 竣工年月 & 用途 \\
\hline Oビル & $\begin{array}{l}\text { 福岡 } \\
60 \mathrm{~Hz}\end{array}$ & $10,633 \mathrm{~m}^{2}$ & $\begin{array}{l}\text { 地上11階 } \\
\text { 地下1階 }\end{array}$ & RC造 & 1992年4月 & 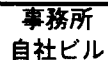 \\
\hline
\end{tabular}

\begin{tabular}{|c|c|}
\hline & 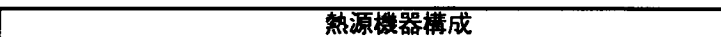 \\
\hline \multirow{13}{*}{$\begin{array}{l}\text { O } \\
\text { ル } \\
\text { U }\end{array}$} & (1)空泠ヒートポンプチラー \\
\hline & 蓄繁時：382.6kW $5^{\circ} \mathrm{C}-12^{\circ} \mathrm{C}$ \\
\hline & 追従時 : $409.4 \mathrm{~kW} 77^{\circ} \mathrm{C}-14^{\circ} \mathrm{C}$ \\
\hline & 荎熱時： $346.6 \mathrm{~kW} 50^{\circ} \mathrm{C}-43^{\circ} \mathrm{C}$ \\
\hline & $57 \%$ RH $\quad$ 追従時： $378.0 \mathrm{~kW} 48^{\circ} \mathrm{C}-41^{\circ} \mathrm{C}$ \\
\hline & 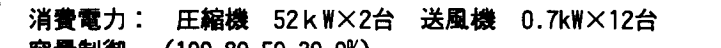 \\
\hline & 容量制御（100-80-50-30-0\%） \\
\hline & (2)ガス焚冷温水発生機 冷温水同時取出型（ABS） \\
\hline & 冷房能力：527kW $7^{\circ} \mathrm{C}-14^{\circ} \mathrm{C}$ \\
\hline & 暖房能力: $460 \mathrm{~kW} 48^{\circ} \mathrm{C}-41^{\circ} \mathrm{C}$ \\
\hline & $\begin{array}{l}\text { 消費ガス量 } 105 \mathrm{~m}^{3} / \mathrm{h}\left[18,837 \mathrm{~kJ} /\left(\mathrm{m}^{3} \cdot \mathrm{h}\right)\right] \text { 消費電力 } 8.6 \mathrm{~kW} \\
\text { 容量制御 }\end{array}$ \\
\hline & 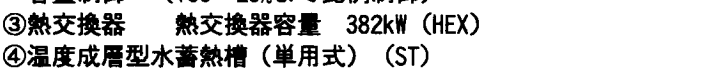 \\
\hline & 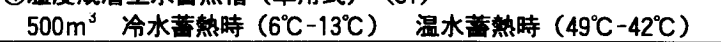 \\
\hline
\end{tabular}

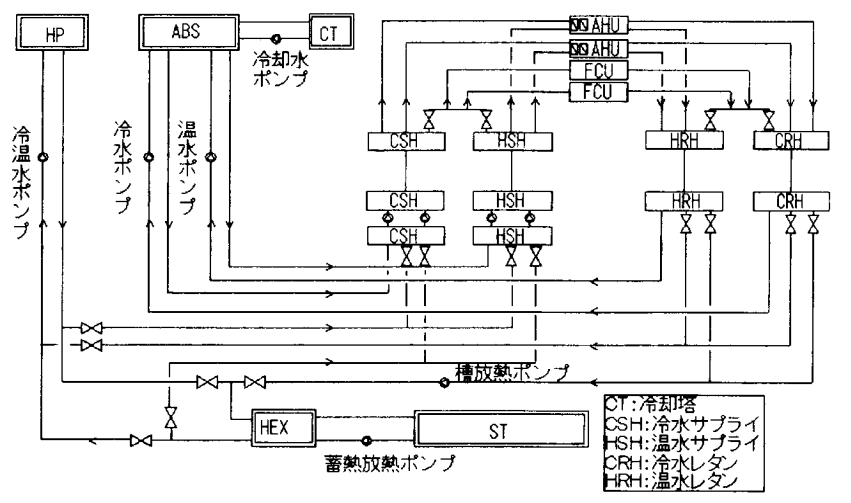

図一１熱源系統図
*1 Graduate School Student, Utsunomiya Univ.
General Manager Engineering Design Division Taisei Corp.
*2 Graduate School Student, Utsunomiya Univ.
*3 Dept. of Architecture and Civil Eng., Utsunomiya Univ., Dr. Eng.
*4 Prof., Dept. of Architecture and Civil Eng., Utsunomiya Univ., Dr. Eng. 


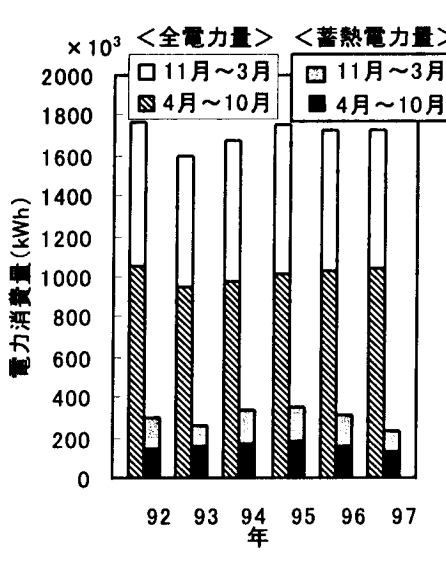

a）全館電力使用量

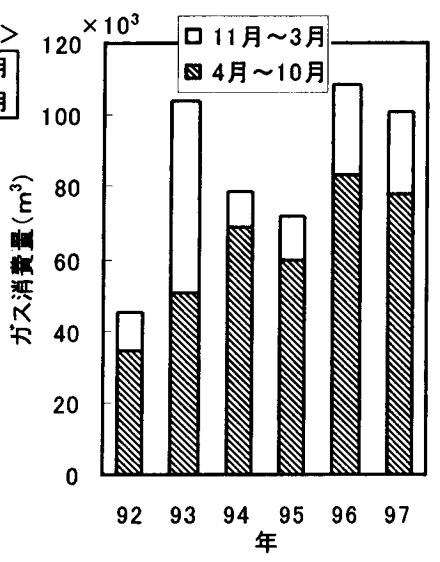

b）熱源ガス使用量

図一2 年間電気・ガス・水道使用量

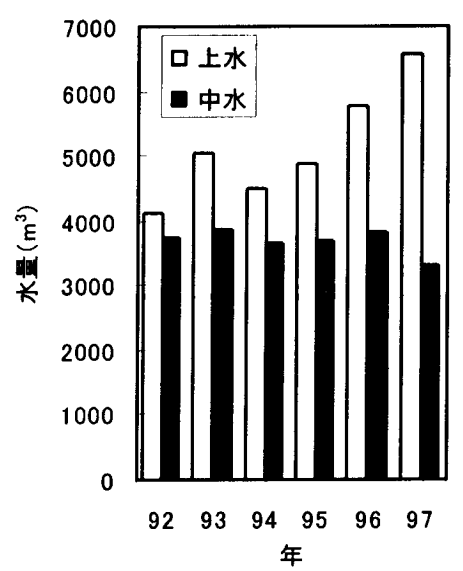

c）全館の上水と中水使用量

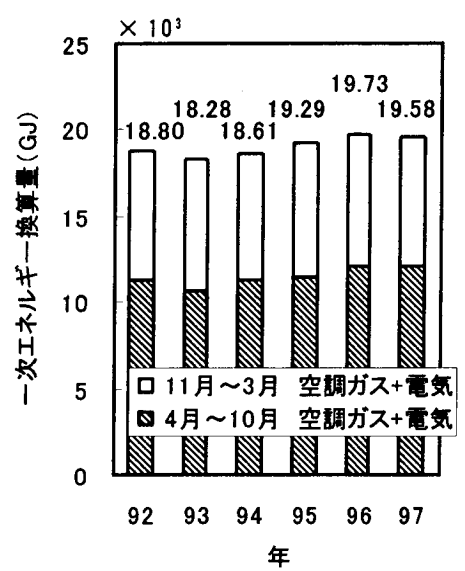

年

图ー3 年間一次エネルギー換算量

\section{（2）年間の実績値}

当ビルは、 92 年 4 月初旬に施工した為、年間の合計值は 5 月より 翌年の 4 月までの值を用いている。図-2に各年の年間電力消費量と ガス消費量と全館の上水と中水の使用量を示す。電気は熱源機器だ けでなく、照明等を含む建物全体の消費量を示すが、年間の変動量 の差は主に熱源機器の稼動状況によるとみなせる。全電力量に占め る熱源設備（1 次ポンプを含む）の電力量の割合は、92 年が約 25.0 $\% 、 93$ 年が約 $21.4 \% 、 94$ 年が約 $25.6 \%$ となっている。ガスは冷暖 房用のみを示す。ガスの発熱量は $18,837 \mathrm{~kJ} / \mathrm{m}^{3}$ である。中水は、便 所の洗浄水に使用している。

図-3に各年の一次エネルギー換算量を示す。一次エネルギーへの 換算值は表 -4 の值を使用した。図 -4 に年閒のランニングコストを示 す。料金体系は、九州電力侏侏西部ガス㑣、福岡市水道局の料金 を使用した。ガスは 4 月より 10 月まで、冷房特約料金を適用してい る。94 年より、7月から 9 月まで電力のピーク時間調整契約を結んで いる。図-5に福岡市の各年の月別平均最高・最低外気温度を示す。 92 年の HP 主体運転と 93 年の ABS 主体運転を比較すると、電力使 用量は、92 年は 93 年より $5.5 \%$ 程度多くなっているが、ガス使用量は、 $43 \%$ 程度となっている。93 年のガス使用量は、冷房と暖房でほぼ同 量となっている。92 年は冷却塔の使用時間が少なくなり、上水の使 用量が少なくなっている。一次エネルギー換算量では、93 年の值が 小さくなっているが、この年は冷夏で負荷が少なかった為といえる。電 気使用量の全体に占める割合が大きい為一次エネルギー換算量の変 化は、電気使用量の変化傾向と同じとなっている。冷房でのエネル ギー消費の方が、暖房より大きいことを示している。ランニングコスト は、両年ともほぼ等しい值となっているが、93 年は負荷が少ないこと を考えると、割高となっている。又、冷房期のみのコストを比べると、 $\mathrm{ABS}$ 主体の方が安く、暖房期はHP 主体の方が安くなっている。そこ で、 3 年目の 94 年は、冷房時は ABS 主体運転、暖房時はHP 主体 運転とした。94年は猛暑の夏で冬も寒い日が多い年で、負荷的には 大きい值となった年であったが、電気消費量もガス消費量も一次エネ ルギー換算量も、前 2 年の中間值程度であった。そしてランニングコ ストは、 93 年に比べて $12 \%$ 程度低下している。この内、ピーク時間 調整契約による電力料金の低下分が $4.6 \%$ 含まれているが、残り $7.4 \%$ は運転モード変更による低減といえる。7月〜9月の間は、午前中の 室内設定温度を $2^{\circ} \mathrm{C}$ 下げて、 $24^{\circ} \mathrm{C}$ 設定とし、13:00から $16: 00$ までの 3 時間は $26^{\circ} \mathrm{C}$ 設定として HPを強制停止している。これにより、 $\mathrm{ABS}$
表ー3 年間の運転モード

\begin{tabular}{|c|c|c|c|}
\hline \multicolumn{2}{|c|}{ 年月 } & 冷房期(4月～10月 & 暖房期(11月～3月) \\
\hline 1992年5月〜 & 993年4月 & $\mathrm{ST} \rightarrow \mathrm{HP} \rightarrow \mathrm{ABS}$ & $\mathrm{ST} \rightarrow \mathrm{HP} \rightarrow \mathrm{ABS}$ \\
\hline 1993年5月〜 & 994年4月 & $\mathrm{ST} \rightarrow \mathrm{ABS} \rightarrow \mathrm{HP}$ & $\mathrm{ST} \rightarrow \mathrm{ABS} \rightarrow \mathrm{HP}$ \\
\hline 1994年5月〜 & 995 年4月 & $\mathrm{ST} \rightarrow \mathrm{ABS} \rightarrow \mathrm{HP}$ & $\mathrm{ST} \rightarrow \mathrm{HP} \rightarrow \mathrm{ABS}$ \\
\hline 1995年5月〜 & 998年4月 & $\mathrm{ST} \rightarrow \mathrm{ABS} \rightarrow \mathrm{HP}$ & $\mathrm{ST} \rightarrow \mathrm{HP} \rightarrow \mathrm{ABS}$ \\
\hline \multicolumn{4}{|c|}{ 表 -4 一次エネルギ一換算值 } \\
\hline & \multicolumn{2}{|r|}{ 電力(kWh) } & 都市ガス $\left(\mathrm{m}^{3}\right)$ \\
\hline 発熱量(kJ) & 昼 & 10,250 & 18,837 \\
\hline
\end{tabular}

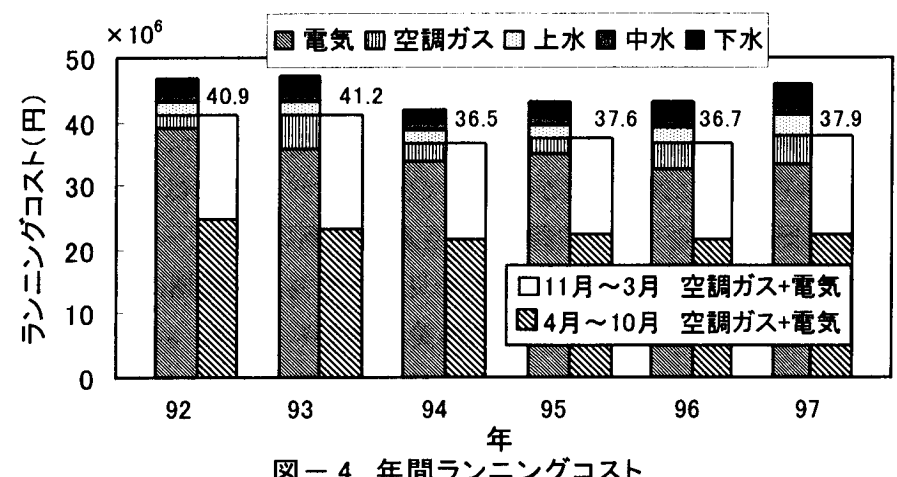

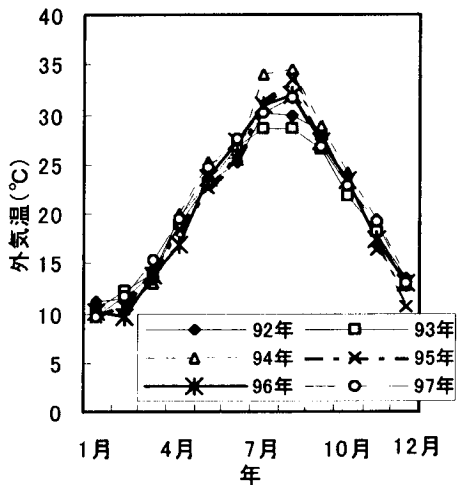

a) 最高気温月別平均
図一 5 福岡市年別外気温

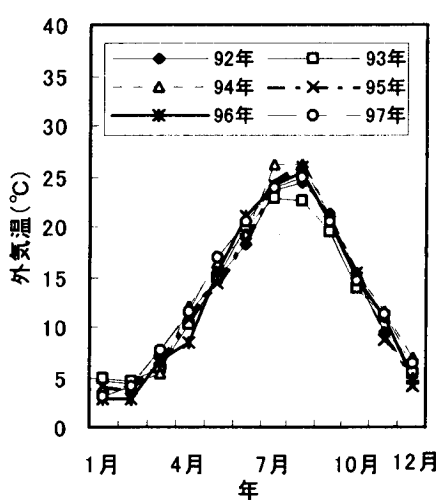

b) 最低気温月別平均
の負荷率も高くなり、高効率運転が行なわれている。

96 年 4 月より、 4 階に入居している住宅関連の子会社が日曜日の営 業を開始し、1 階ロビー・2 階応接も含めて、空調時間が増大すること となった。上水の使用量も増大している。98年 3 月には蓄熱槽の清掃 と水替えを行なっている。上水と中水の比率は、平均 56:44となってい る。 


\section{2. 中間期の運転モード変更による実測結果}

夏・冬のピーク時にST、HP、ABS をすべて運転するときの運転方 法は、3 年間の実測結果より、方向性は出せたが、中間期は、一部 の熱源機器のみの運転で負荷が処理できるので、どの機器を選定して 運転したら効率が良いか調べる為、実測を行なった。表 -5に示すよ うに、 96 年 10 月と 97 年 5 月〜 6 月、 10 月の冷房期で 3 期間、 97 年 2 月〜 4 月の暖房期で 1 期間、運転モードを変更して低負荷時の運転 実測を行なった。

冷房中間期の期間平均負荷は約 $290 \mathrm{~kW}$ で、各熱源機器単体で負 荷を処理できる時間数が多い事を示している。ケースAは、STで主 に負荷を処理しているが、負荷が多い日には、HPが低負荷で追従運 転をしている。ケースBは、STを使用せずHPで主に負荷を処理して いる。ケース C は、ST の蓄熱温度を冷房期 $4{ }^{\circ} \mathrm{C}$ 上昇させ、暖房期は $4^{\circ} \mathrm{C}$ 低下させて、STを主体に運転を行なっている。しかし、冷房期に おいては、室内設定温度に往還水温度が近づく為、空調コイルで温 度差がつかず、その結果 ST の出力が減少し、負荷処理能力が不足 し、HP の追従運転が頻繁に行なわれている。ケースD は、STを使 用せず、 $\mathrm{ABS}$ のみで負荷を賄っている。

表 - 6 に 97 年の 10 月の各モード毎の各熱源機器の日平均負荷分担 と冷房負荷を示す。值の表は省略するが暖房期は立上がり時の負荷 が大きく、朝の $1 \sim 2$ 時間のみ追従機器の運転が行なわれており、日 中はほとんどの時間、単独運転となっている。表-7に各モード毎の、 熱源機器の平均 $\mathrm{COP}$ と平均外気温を示す。ケース A、Cから HP の 泠房蓄熱時は、送水温度を日中より低く設定しているのにもかかわら ず、外気温度が $2 \sim 3{ }^{\circ} \mathrm{C}$ 低いのと、機器の高負荷率運転により日中 のCOPより $8 \sim 12 \%$ 程度高くなっている。暖房時は、外気温が低い のにもかかわらず、蓄熱時の方が HPの COPが良い值となっている。 これは、ケース AとBを比べてみて、機器の負荷率の違いによるもの と思われる。

表 -8 に中間期のST の熱損失量を示す。熱損失量は、24 時間自 然放熱による加重平均水温の変化を理論的满蓄量で割って求めた。 中間期は外気温と蓄熱水温との差が少なくなるため、ピーク負荷時よ り値は小さくなっている。

運転モードを変更した場合のエネルギー消費量とランニングコストを比 較する為、発生負荷 $1 \mathrm{GJ}$ 当りの一次エネルギー換算量と従量料金を 算出した。ここでの電気量は一次ポンプを含む熱源設備についてのみ の値を使っている。

図-6に、発生負荷 $1 \mathrm{GJ}$ 当りの熱源設備の一次エネルギー換算量の 比を示すが、冷房期は蓄熱槽の送水温度を上昇させたケース C が もっともエネルギ一消費量が少ないことを示している。ケースCは、HP の追従運転が行なわれているが、その送水温度も蓄熱槽の送水温度
に合わせて上昇させている。その次は蓄熱槽を使用しない、HPのみ の運転モードのケースBとなっている。しかし、ケースAからCまでは 大差がないといえる。ABS は、低負荷時の効率が低く、エネルギー 消費量が多くなっている。

暖房期は、蓄熱槽を使用しないHPのみの運転のケースBがもっとも エネルギー消費量が少なくなっており、他のケースは大差がない。こ れは、冬期の蓄熱槽の熱損失や、HPの低負荷運転による効率低下、 夜間の外気温の低下、ABS の暖房時の効率の低下に起因する。

図-7に発生負荷 $1 G J$ 当りの従量料金を示す。ランニングコスト的に は冷房期、暖房期共に蓄熱槽を利用したケースが安く、冷房期は蓄 熱槽の設定温度を変更しても、それほどランニングコストには影響がな いといえるが、暖房期は設定温度を下げた効果が現れている。冷房、 暖房共、ABS 主体より HP 主体の方がランニングコストは安くなってい る。

表 - 5 中間期の運転モードと実測期間

a) 冷房期温度条件

\begin{tabular}{|c|c|c|c|}
\hline ケース & 運転パターン & 期间 & 远転条件(設定温度) \\
\hline A & $\begin{array}{l}\mathrm{ST} \rightarrow \mathrm{HP} \rightarrow \mathrm{ABS} \\
\text { 䓵熱槽主体䦽転 }\end{array}$ & $\begin{array}{l}96 / 10 / 1 \sim 10 / 6 \\
97 / 5 / 12 \sim 5 / 16 \\
97 / 10 / 1 \sim 10 / 9\end{array}$ & 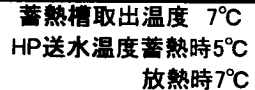 \\
\hline B & $\begin{array}{c}\mathrm{HP} \rightarrow \mathrm{ABS} \\
\text { ヒートポンプチラー主体運転 }\end{array}$ & $\begin{aligned} 96 / 10 / 7 & \sim 10 / 13 \\
97 / 5 / 21 & \sim 5 / 22 \\
97 / 10 / 14 & \sim 10 / 17\end{aligned}$ & 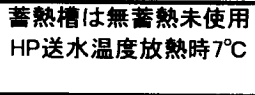 \\
\hline c & 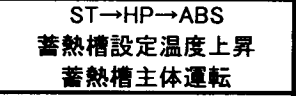 & $\begin{aligned} 96 / 10 / 14 & \sim 10 / 20 \\
97 / 6 / 2 & \sim 6 / 6 \\
97 / 10 / 20 & \sim 10 / 24\end{aligned}$ & $\begin{array}{r}\text { 荎熱槽取出温度 } 11^{\circ} \mathrm{C} \\
\mathrm{HP} \text { 送水温度蓄熱時 } 9^{\circ} \mathrm{C} \\
\text { 放熱時 } 11^{\circ} \mathrm{C}\end{array}$ \\
\hline D & $\begin{array}{c}\text { ABS } \\
\text { 冷温水発生機主体運転 }\end{array}$ & $\begin{aligned} & 96 / 10 / 21 \sim 10 / 26 \\
& 97 / 6 / 9 \sim 6 / 13 \\
& 97 / 10 / 29 \sim 10 / 31 \\
&\end{aligned}$ & $\begin{array}{l}\text { 菩熱樯は無蓄熱未使用 } \\
\text { ABS 送水温度 } 7^{\circ} \mathrm{C}\end{array}$ \\
\hline
\end{tabular}

b) 暖房期温度条件

\begin{tabular}{|c|c|c|c|}
\hline ร-ス & 通転パターン & 期间 & 䇛転条件（設定温度） \\
\hline A & $\begin{array}{c}\mathrm{ST} \rightarrow \mathrm{HP} \\
\text { 荎慜槽主体通転 }\end{array}$ & $97 / 2 / 24 \sim 3 / 1$ & 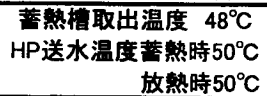 \\
\hline B & $\begin{array}{c}\mathrm{HP} \rightarrow \mathrm{ABS} \\
\text { ヒートポンプチラー主体運転 }\end{array}$ & $97 / 3 / 5 \sim 3 / 15$ & 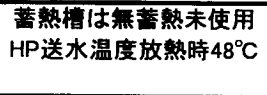 \\
\hline c & 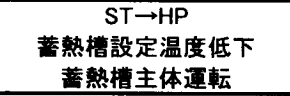 & $97 / 3 / 17 \sim 4 / 2$ & $\begin{array}{r}\text { 蓄熱偻取出温度 } 44^{\circ} \mathrm{C} \\
\text { HP送水温度蓄熱時 } 46^{\circ} \mathrm{C} \\
\text { 放熱時 } 44^{\circ} \mathrm{C}\end{array}$ \\
\hline D & $\begin{array}{c}\text { ABS } \\
\text { (冷温水同時取出) } \\
\text { 冷渴水発生機主体通転 }\end{array}$ & $97 / 4 / 7 \sim 4 / 11$ & $\begin{array}{l}\text { 温水送水温度 } 47^{\circ} \mathrm{C} \\
\text { 冷水送水温度 } 7^{\circ} \mathrm{C}\end{array}$ \\
\hline
\end{tabular}

表一 6 各モード毎の各熱源機器日平均負荷分担割合と冷房負荷 1997年10月（単位 GJ/日）

\begin{tabular}{|c|c|c|c|c|}
\hline 5-X & A & B & C & D \\
\hline ST & 8.25 & 0.00 & 5.48 & 0.00 \\
\hline HP & 3.39 & 8.58 & 4.90 & 0.00 \\
\hline ABS & 0.69 & 0.08 & 0.25 & 5.44 \\
\hline 合計 & 12.31 & 8.66 & 10.63 & 5.44 \\
\hline \hline 期間ピ-万負局 $(\mathrm{kW})$ & 421.0 & 308.7 & 409.6 & 271.1 \\
\hline 期間平均負荷 $(\mathrm{kW})$ & 301.3 & 228.3 & 273.7 & 170.1 \\
\hline
\end{tabular}

表ー7 各運転モードの熱源機器平均 COP と平均外気温

\begin{tabular}{|c|c|c|c|c|c|c|c|c|c|c|c|c|}
\hline \multirow{2}{*}{ ケース } & \multicolumn{8}{|c|}{ 冷房期 } & \multicolumn{4}{|c|}{ 暖房期 } \\
\hline & \multicolumn{2}{|c|}{$\begin{array}{r}A \\
\end{array}$} & \multicolumn{2}{|c|}{$\mathrm{B}$} & \multicolumn{2}{|c|}{$\begin{array}{c}\mathrm{C} \\
\end{array}$} & \multicolumn{2}{|c|}{$\mathrm{D}$} & $\mathbf{A}$ & $\mathrm{B}$ & $c$ & D \\
\hline 年/月 & $97 / 5 \cdot 6$ & $97 / 10$ & $97 / 5 \cdot 6$ & $97 / 10$ & $97 / 5 \cdot 6$ & $97 / 10$ & $97 / 5 \cdot 6$ & $97 / 10$ & \multicolumn{4}{|c|}{$97 / 2 \sim 4$} \\
\hline HP蓄鄎時COP & 2.83 & 2.73 & - & - & 2.89 & 3.07 & - & - & 2.28 & - & 2.28 & - \\
\hline HP追従時COP & 2.63 & 2.43 & 2.92 & 2.81 & 2.84 & 2.80 & 2.18 & - & 1.97 & 2.41 & 2.22 & - \\
\hline $\begin{array}{c}\text { ABS COP } \\
\text { (低位発熱量. } \\
\text { 本体㭪機含) }\end{array}$ & 0.37 & 0.65 & 0.31 & 0.41 & 0.69 & 0.88 & 0.98 & 1.07 & - & 0.67 & - & 0.69 \\
\hline $\begin{array}{c}\text { 夜间平均外気温 }\left({ }^{\circ} \mathrm{C}\right) \\
(22: 00 \sim 8: 00)\end{array}$ & 20.8 & 19.1 & 15.6 & 15.6 & 21.8 & 18.8 & 20.8 & 13.2 & 10.9 & 11.8 & 9.0 & 12.4 \\
\hline $\begin{array}{c}\left.\text { 日中平均外気温( }{ }^{\circ} \mathrm{C}\right) \\
(8: 00 \sim 22: 00)\end{array}$ & 23.2 & 22.2 & 18.6 & 19.8 & 22.6 & 22.2 & 22.6 & 13.5 & 14.0 & 13.8 & 10.8 & 14.6 \\
\hline
\end{tabular}

表 -8 中間期自然放熱時の蓄熱槽熱損失量

\begin{tabular}{|c|c|c|c|}
\hline & $\begin{array}{c}\text { 槽内平均温度 } \\
{ }^{\circ} \mathrm{C} \\
\end{array}$ & 年月日 & $\begin{array}{c}\text { 熟損失且 } \\
\%\end{array}$ \\
\hline \multirow{3}{*}{$\begin{array}{l}\text { 冷 } \\
\text { 房 } \\
\text { 期 }\end{array}$} & \multirow{3}{*}{$7.2 \sim 7.6$} & $96 / 10 / 25$ & 4.1 \\
\hline & & $96 / 10 / 26$ & 3.7 \\
\hline & & $96 / 10 / 27$ & 3.4 \\
\hline \multirow{6}{*}{$\begin{array}{l}\text { 暖 } \\
\text { 房 } \\
\text { 期 }\end{array}$} & 44.4 & $97 / 3 / 9$ & 7.3 \\
\hline & 39.3 & $97 / 3 / 15$ & 8.7 \\
\hline & 44.0 & $97 / 3 / 20$ & 7.6 \\
\hline & \multirow{3}{*}{$28.5 \sim 28.9$} & $97 / 4 / 8$ & 1.5 \\
\hline & & $97 / 4 / 9$ & 1.7 \\
\hline & & $97 / 4 / 10$ & 1.6 \\
\hline
\end{tabular}




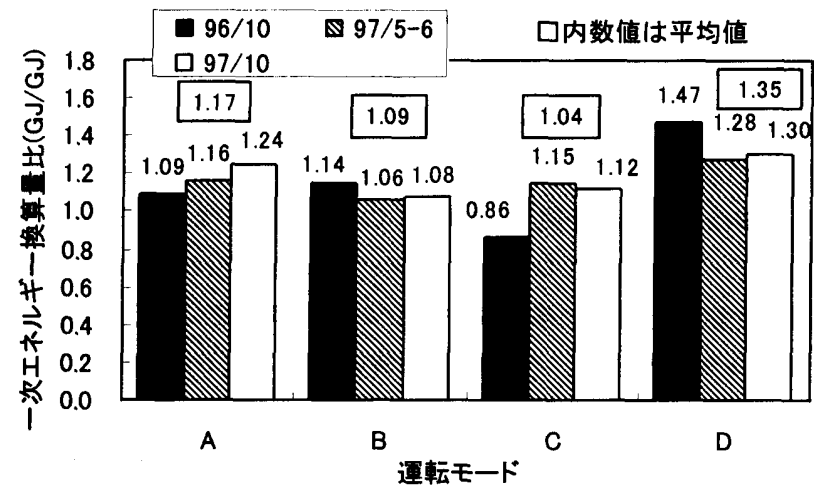

a) 冷房期

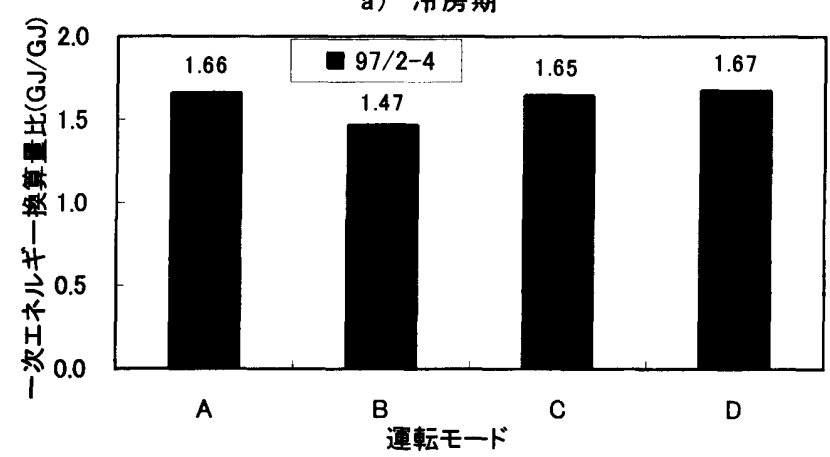

b) 暖房期

図ー6 運転モード毎の1G」当たりのー次エネルギー換算量比

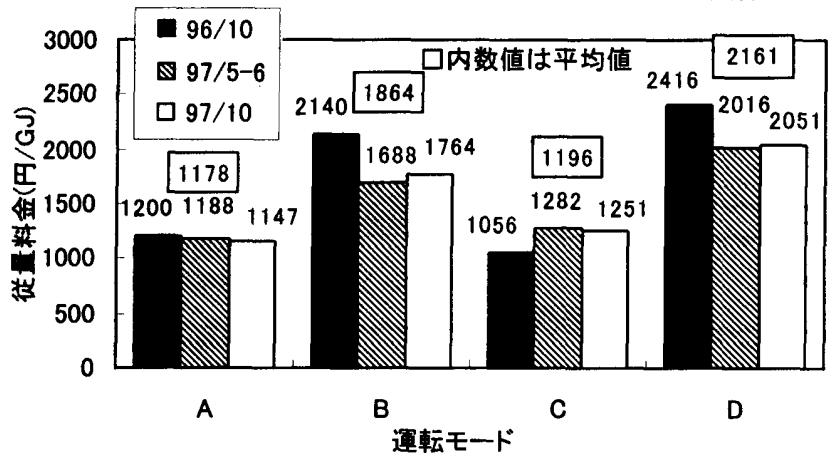

a) 冷房期

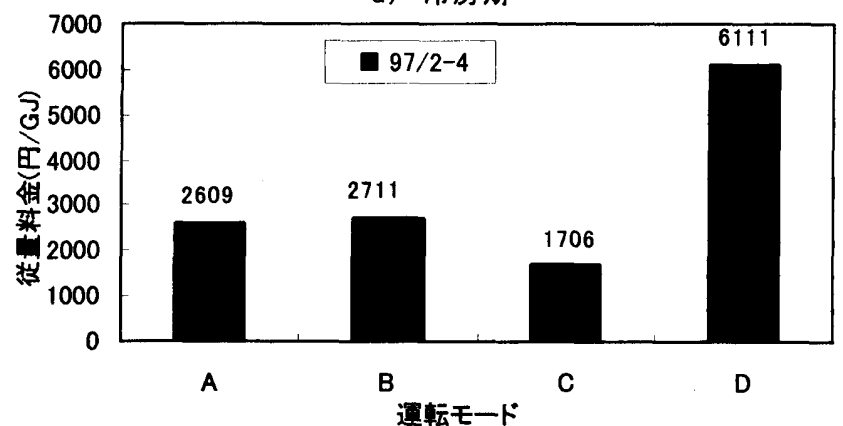

b) 暖房期

图ー7運転モード每の1GJ 当たりの従量料金

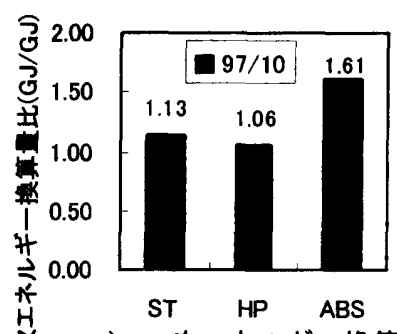

a) 一次エネルギー換算

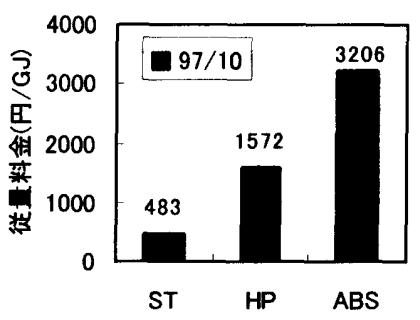

b) 従量料金

図ー8 運転モード每の $1 \mathrm{GJ}$ 当たりの一次エネルギー換算量比と 従量料金のシミュレーション結果

\section{3. 中間期のシミュレーション結果}

実測結果では、各熱源機器が完全に単独で運転しているわけでな く、一部他の熱源が同時に運転されている時間も含むので、97 年 10 月の1ヶ月の実測負荷と、実測 COPを用いて、STとHPとABSの容 量を実際の值より増大させて、単独で運転した場合のエネルギー消費 量とランニングコストをシミュレーションで求めた。6) 計算条件として、 蓄熱槽の熱損失量は $3 \%$ とし、機器の COP は外気温と負荷率により 変動させ 1 時間毎の計算を行った。

図-8に示す結果より、一次エネルギー換算的には、HP 単独運転 が、ランニングコスト的には蓄熱槽を優先運転するのが有利となり、実 測結果の傾向と同じとなった。

4. まとめ

複合熱源蓄熱システムの中間期低負荷時の運転手法について、実 運転データの解析により、次のようなことが分かった。

(1) 冷房期

(1)エネルギー消費量については、低負荷時の効率が、ガス焚冷温 水発生機に比べて、空冷ヒートポンプチラーの方が良いので、空 冷ヒートポンプチラーのほうが少ない。

(2)蓄熱システムは、槽内外温度差が小さくなるので熱損失量も少な くなり、夜間の外気温の低下と高負荷運転による負荷率の向上に より、非蓄熱システムとの消費エネルギーの差は小さくなる。

(3)ランニングコストは、蓄熱システムがかなり安く有利となる。次に空 冷ヒートポンプチラーが安くガス焚冷温水発生機は高くなっている。 従って、夏のピーク時は、ガス焚冷温水発生機にフルロードがかか るように、運転順序を蓄熱槽一ガス焚泠温水発生機一空冷ヒートポン プチラーとしており、冷房時は中間期もこの順序で運転して来たが、 以上のことから、ガス焚冷温水発生機の負荷率が下がり、蓄熱槽と空 冷ヒートポンプチラーのみで負荷を賄える時期には、蓄熱槽 $\rightarrow$ 空冷 ヒートポンプチラー運転に切替えるのが良いと言える。

(2) 暧房期

(1)エネルギー消費量は、非蓄熱システムの空冷ヒートポンプチラー の単独運転が有利となる。

(2)蓄熱システムは、夏期と比べて槽内外温度差が大きく、ピーク時 よりは少ないが、熱損失もあり、夜間の外気温度の低下による空 冷ヒートポンプチラーのCOPの低下もあり、消費エネルギーが增 大する傾向がある。

(3)ランニングコストは、蓄熱槽を利用した方が安く、有利となる。 従って、暖房の中間期の運転は、ピーク時と同じように運転順序は 蓄熱槽 $\rightarrow$ 空冷ヒートポンプチラーー冷温水発生機とするのが良い。

謝辞

辞 助教授、久留米工大西山紀光教授、大成建設森)斧田浩一氏、岡部裕之氏、小 林光氏、宇都宮大学 高橋進二氏、成サービス珠九州支店の方々の多大なご協 力をいただきました。ここに記して感謝の意を表します。

参文献

高橋淳一、岡部裕户他: 複合熱源蓄熱システムの低負荷時の高効率運転

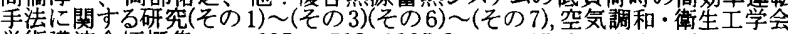
学術講演会梗概集, pp.697 - 708 1997.8 $\quad$ pp.1773-1780 1998.8

2) 高橋溥二、他: Hybrid energy system \& temperature stratified thermal storage tank installed on medium-scale general office building. MEGASTOCK 7

3）岡部裕之 高棉淖一、他: 事務所ビルの電気・ガス複合熱源空調システムに

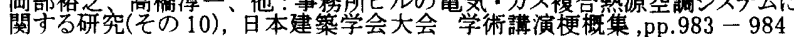
1995.8

4） 1995.8 龍有渡辺俊行、他: 中規模事務所ビルにおける重気・ガス複合溯源蓄熱

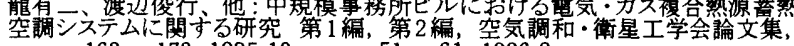

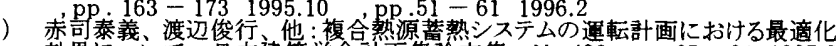

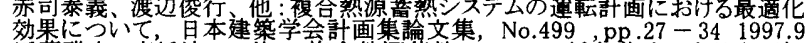

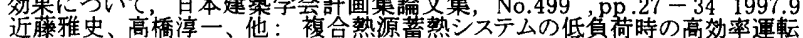

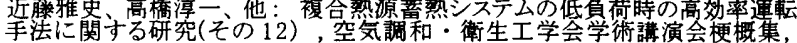
pp.997- 10001999.9

[1999年 4 月20日原稿受理 